\title{
To What Extent the Meaning of Different Types of Ironies in King Lear is Translated and Transferred into Persian by Beh Azin (2012) and Peyman (2002)
}

\author{
Mahnaz Havas Beygi \\ Department of Translation Studies, East Azarbaijan Science and Research Branch, Islamic Azad University, Tabriz, \\ Iran \\ Biook Behnam \\ The English Language Department, Islamic Azad University, Tabriz, Iran
}

\begin{abstract}
Translation has always been a way of communication among different cultures and plays a key role in transferring ideas, information, social and cultural aspects of the source language into target languages and its impact on various aspects of human life is undeniable. There are various theories, strategies, methods, and different types of translation in order to achieve an appropriate translation product. The aim of this study was to know how different types of ironies in Shakespeare's King Lear are translated into Persian and which ironies remain untranslated. In order to achieve this aim, different types of irony have been chosen as the unit of translation. The corpus of the study as mentioned above, is a tragic play entitled, King Lear, written by William Shakespeare and its Persian translations by Beh Azin and Peyman.
\end{abstract}

Index Terms — translation, culture, irony, King Lear

\section{INTRODUCTION}

Translation has always been a way of communication among different cultures and plays a key role in transferring ideas, information, social and cultural aspects of the source language into target languages and its impact on various aspects of human life is undeniable.

\section{LITERATURE REVIEW}

\section{A. What is Translation?}

Dostert (1955, p. 124) says translation is "the transference of meaning from one patterned set of symbols occurring in a given culture... into another set of patterned symbols in another culture...." In Larson's (1984, p. 431) view in the process of translation all meaning is culturally conditioned and the response to a given text is also culturally conditioned. Each society

\section{B. What is Culture?}

Goodenough (1964, p.167) believes that "A society's culture consists of whatever it is one has to know or believes in order to operate in a manner acceptable to its members, and to do so in any role that they accept anyone of themselves."

\section{What is Irony?}

There are different definitions for "Irony" and different scholars have worked on the concept of irony from different points of view. Therefore, giving an exact and comprehensive definition of irony is not a straightforward activity. Some of these definitions are as follow;

Muecke (1969, p.7) believes that the concept of irony is vague, unstable and multiform. The word 'irony' does not now mean only what it meant in earlier centuries, it does not mean in one country what it meant in another, nor to one scholar what it may meant to another.

Based on the classical definition of irony, Cutler (1974, p.117), in her article "On Saying What You Mean without Meaning What You Say," considers that an ironic utterance expresses a conveyed meaning which is the "opposite," "converse" or "reverse" of its literal meaning. She also states that the speaker produces this kind of utterance "by superimposing a certain intonation contour which signals to his hearers that the utterance is intended to be ironic."

Irony is, in Linda Hutcheon's words, "the mode of the unsaid, the unheard, [and] the unseen" (1994, p.9).

Corbett \& Connors (1999, p. 379) categorizing irony as a trope means that irony is a form of figurative language that includes "a deviation from the ordinary and principal signification" of an utterance. 


\section{The Elements of Irony}

In his entry on irony, Abrams (1985, pp. 97-100) defines nine categories and subcategories of irony--verbal, structural, stable and unstable, Socratic, dramatic, tragic, cosmic, and Romantic--along with comments upon several related terms (sarcasm, invective, and so on).

Cutler (1974, p. 119) makes a distinction between "spontaneous" and "provoked" irony. In the former, "the speaker is expressing 'what he/she means' with no reference to previous context or conversation". The utterances belonging to the spontaneous category must be approbatory in the literal reading. On the other hand, in a "provoked irony", the speaker "repeats back to his audience something which the audience has previously said or held, with the ironic intonation indicating that the previous claim has turned out to be wrong". Cutler states that a "provoked irony" also meets the "Approbation Condition."

\section{E. Three Types of Irony}

Irony is a literary term underlying different definitions and various categories by scholars from Socrates era up to nowadays. Among the types of irony, this paper will focus on three of them: verbal irony, dramatic irony which is the most predominant in Shakespeare's King Lear according to the present research, and irony of situation, as described below.

\section{a. Verbal Irony:}

Abrams (1985, p. 97) argued that verbal irony (which was traditionally classified as one of the tropes) is a statement in which the meaning that a speaker implies differs sharply from the meaning that is ostensibly expressed. The ironic statement usually involves the explicit expression of one attitude or evaluation, but with indications in the overall speech-situation that the speaker intends a very different, and often opposite, attitude or evaluation.

\section{b. Dramatic Irony:}

In Abrams' (1985, p. 99) view dramatic irony involves a situation in a play or narrative in which the audience or reader shares with the author knowledge of present or future circumstances of which a character is ignorant; in that situation, the character unknowingly acts in a way we recognize to be grossly inappropriate to the actual circumstances, or expects the opposite of what we know that fate holds in store, or says something that anticipates the actual outcome, but not at all in the way that the character intends.

\section{c. Situational Irony:}

Irony of situation is a discrepancy between the expected result and actual results. It deals with the unexpected and the incoherent situations. This situational irony is embedded in an environment where the universe seems to be against you, in other words, when the unexpected happens. (Izaias, 2011)

\section{MethodOLOGY}

By considering the kind of research, the present study utilizes the descriptive nature and qualitative type, comparing Shakespeare's King Lear (20th century, 1998, Collins Edition) ironies to its Persian translations by Beh Azin (2012) and Peyman (2002).

For this purpose and doing it properly, the researcher was interested in and familiar to 'King Lear play' and studying it over and over to find the different types of irony as a word, a phrase, a sentence, a whole scene or act and generally everything that convey the ironic sense in the play and then decided to do the work in the way that she can determine which ironies are translated by the two selected translators and to see whether the translations have been able to convey the ironic meaning of those different types or not. Or to find missing ironies in target texts or mistranslation of them to the extent in which the source text meanings are not conveyed as the writer intended to do. It should be mentioned that this play has been translated into Persian by many of Persian translators.

The researcher had studied the play from the very beginning and whenever she find an irony of each type as previously said, will compare it to its translation in both selected versions to find out whether they are translated adaptably or mistranslated or even denied in the process of translation.

\section{Procedure and Data Analysis}

In the present study, since the aim of research is to deal with the source text ironies and their equivalence in target text, the unit of translation is considered to be different types of irony in both the original work of "King Lear" and its equivalent in Persian translations from Beh Azin (2012) and Peyman (2002).

The aim of the procedure is to see whether the ironies of the original text are translated into Persian due to cultural differences between source text and target text by the two translators.

Further, it will be investigated whether there is any deletion or addition of ironies of "King Lear" in both translations. In order to do that, there will be accurate explanations of some kinds of ironies which are not directly mentioned and should be inferring from the situation or chain of events in the play. There would be also tables to provide useful information for the readers. Each table will followed by a comment on types of ironies and an analysis of two types of translations to show the ability of the two Persian translators namely, Beh Azin and Peyman in conveying ironies from the source text as much as possible according to translation types they applied. This procedure of data analysis is shown in the following attached sample. The frequency and percentage will be shown in a diagram.

At the end, a conclusion is drawn based on the purpose of the study. 


\section{DATA ANALYSIS}

Here we will provide a small number of examples, taken from Shakespeare's King Lear to illustrate the translation of irony into Persian more operationally. The following examples will be discussed, mainly on the basis of three types (verbal irony, dramatic irony, and situational irony) category.

Source text:

Lear.

Meantime we shall express our darker purpose. (p.11)

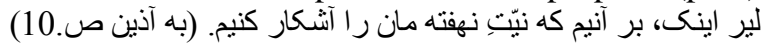

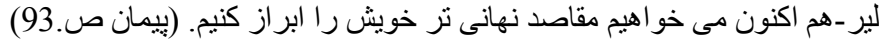

Here the word "darker" is used ironically. On the surface, it means "hidden" and "unspoken". However, Lear's "hidden" purpose is actually "dark", i.e. horrible and gloomy, since it will lead to his downfall and death. The audience, unlike Lear himself, knows about the "darkness" that will follow Lear's decision to divide his kingdom. Shakespeare conveys his dramatic irony through a verbal irony. In none of the two translations the irony involved in word "darker" has been transferred. They both change the literal meaning of "darker" in order to create a more natural Persian equivalent.

Source text:

[Enter Edgar]

Pat!- -he comes, like the catastrophe of the old comedy: my cue is villainous melancholy, with a sigh like Tom o' Bedlam, (p.29)

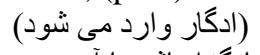

درست به موقع مى آيد، مانند حادثه ناكهانى در يايان بندى نمايش هاى قديم. حالتى كه به خود مى كيرم بايد نشانكر اندو هى جانكز ا باثد با آهى ....

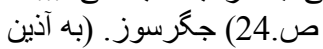

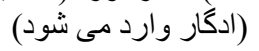

هم اكنون او بسان بلايى در يكى كمدى نيمه تمام وارد مى شود: دنباله سخن من بايد افسردگى شديدى تو أم با آهى همجون آن دريوزة ديو انه خانه باثد، ص.بيم. 115) (بيمان

In this sample;

- The word catastrophe signifies the conclusion of a play, referring to predictable comedies which resolve the dramatic conflict in the nick of time. Ironically, at the end of the play, Edgar enters upon Edmund as a catastrophe and puts an end to his villainous acts. The Audience knows this, but Edmund does not.

- Tom o' Bedlam had been a madman from Bethlehem (Bedlam) Hospital, this ironically shows Edgar will later take on this disguise and singing to himself could be a sign of this madness. Despite difference in wording, both Beh Azin and Peyman convey the irony involved in the English text in the same way.

Source text:

Fool.

Shalt see thy other daughter will use thee kindly; for though she's as like This as a crab's like an apple, yet I can tell what I can tell. (p.50)

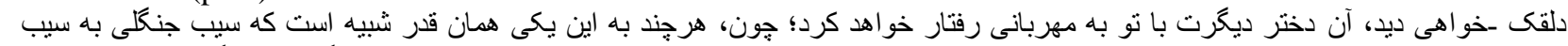

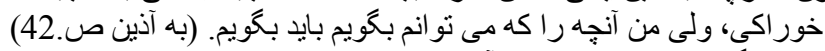

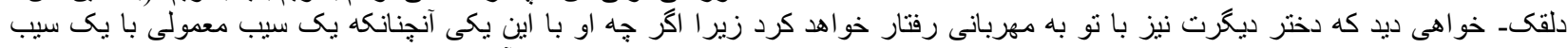

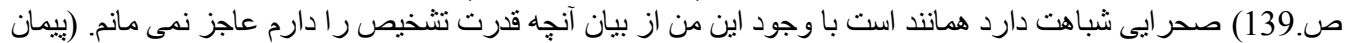

Fool by using "this" compares Regan to her sister Goneril; although the two sisters don't look alike, they will "taste" alike.

Kindly has two meanings here; 1) with compassion; 2) according to her kind. Her kind is the same as her sister's and it is metal (steel). It means that Regan will treat you just as hardly as Goneril.

Only Peyman conveys the Irony. He has added the word "نيز" and conveys the double meaning in the word "kindly".

Source text:

Lear.

Beloved Regan,

Thy sister's naught: O Regan, she hath tied Sharp-tooth'd unkindness, like a vulture, here,--[Points to his heart.] I can scarce speak to thee; thou'lt not believe With how deprav'd a quality--O Regan! (p.75)

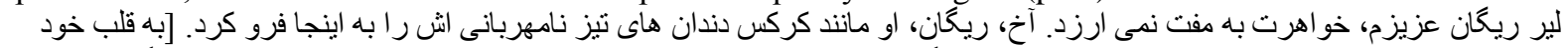

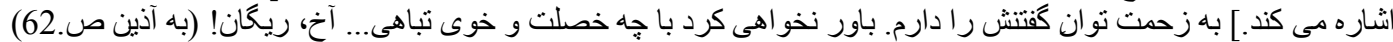

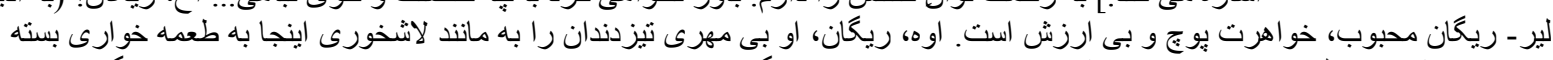

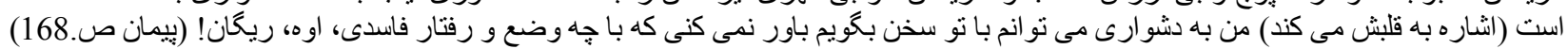

It is ironic that the King has referred Goneril's cruel treatment of him to Regan. He should know that Regan is much crueler than Goneril. Also, he is unaware that Goneril has informed Regan of what had passed between her and Lear and has asked Regan to do the same. The audience knows what the king doesn't. Beh Azin's translation is too literal and slavish. For example, he translates the phrase "thou'lt not believes" as future tense, which is not common in Persian. Peyman's text is more smooth and natural. Since the irony is not verbal, both recreate it.

Source text: 
Regan

$\mathrm{O}$, sir, you are old;

Nature in you stands on the very verge Of her confine: you should be rul'd and led By some discretion, that discerns your state Better than you yourself. Therefore, I pray you, That to our sister you do make return; Say you have wrong'd her, sir. (p.76)

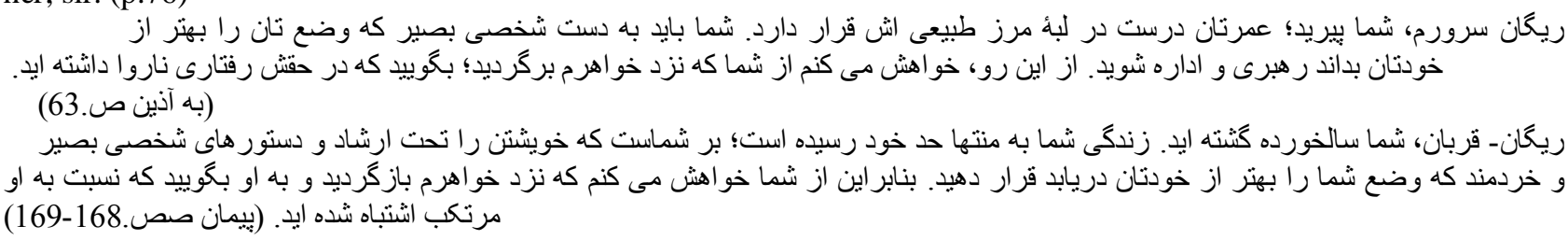

Regan, apparently out of pity, tells her father that Goneril knows his "state" better. The word state also means "government". Therefore, it is an ironic way of telling the King they are better rulers, and that he should be happy to be governed by his daughters. In Beh Azin, all the meanings surrounding the word "state" are present (رهبري و اداره), therefore the irony is there. In Peyman the irony is lost. However, Peyman's language seems like an original text.

Source text:

Cornwall

I set him there, sir: but his own disorders Deserv'd much less advancement. (p.79)

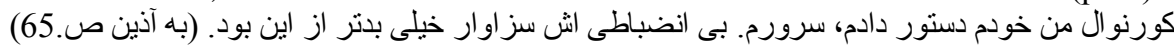

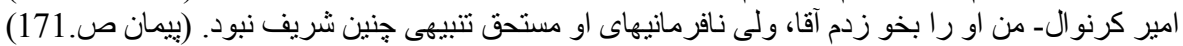

Cornwall tells the King that Kent's rudeness “deserved much less advancement” (promotion). It is sarcastic, since Kent has not been promoted, he has been punished. Both Beh Azin and Peyman make changes to the ST to make better sense. However since they have mistranslated the word "advancement", the irony is lost in both.

Source text:

Gloucester

Because I would not see thy cruel nails Pluck out his poor old eyes; (p.110)

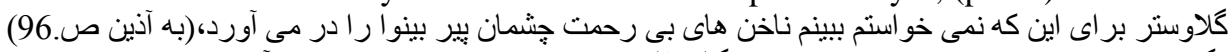

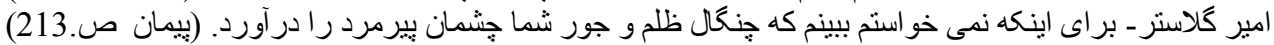

- Cosmic irony: Regan captures Gloucester before he leaves for Dover to join Lear. When she asks him about the reason, Gloucester says that he is doing so because he doesn't want to see Regan pluck out the old man's eyes (i.e. Lear's eyes). His wish is fulfilled but ironically. He will not see anything, because he himself will be blinded.

- Irony of situation: Gloucester, who doesn't want to see Lear be blinded, will see Ragan and Cornwall blind himself.

In Beh Azin the translation is exact and the irony is there. In Peyman the word "Persian" has been replaces by only one of its meanings (rich), therefore the irony is lost. Since Persian also connotes "a far and alien land" and points to the "distance" between Lear and Edgar.

Source text:

Gloucester

O my follies! Then Edgar was abus'd.--Kind gods, forgive me that, and prosper him! (p.113)

كلاوستر واى بر من از حماقت هايم! پِّ، رفتارم با ادكار خطا بود. ایى خدايان مهربان، از من اين را دركذريد، او را بركت دهيد!

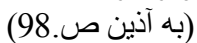

امير كلاستر - تف بر اشتباهاتم، بِ با ادكار بدرفتارى شده- خدايان مهربان خطاى مر ا بيخشيد و او را كامياب و بيروز كردانيد.

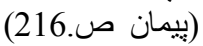

Soon after being blinded, Gloucester finds out the truth about Edmund and Edgar. It is ironic that he could not see the truth when he had two healthy eyes, but sees the truth when he loses his eyes. In Beh Azin the TT follows the rules of Farsi, but in Peyman the TT unnatural and unsmooth. However, since the irony is situational, not verbal, both transfer the irony.

Source text:

Edgar

Know, my name is lost;

By treason's tooth bare-gnawn and canker-bit.

Yet am I noble as the adversary I come to cope. (p.163)

ادكار دانسته باش، نامم كم شده؛ دندان هاى خيانت آن را خاييده و خورهوار خورده. با اين همه، من مانند حريفى كه به جنكث آمده ام اصيل زاده ام.

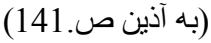

ادكار - بدانيد كه نام من از ميان رفته و دندان خيانتكار كرم نا بكار جامهُ اسم و رسم مر ا جويده وعريانم ساخته است و باوجود اين به اندازه ششمنى كه آنه

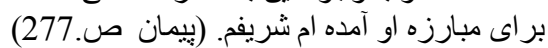

Before starting his combat with Edmund, Edgar is asked by the Herald to introduce himself to the viewers. In response, Edgar says that he has lost his name (title), but he is as noble as the one he is challenging (Edmund).

-Irony of situation: It is ironic that Edgar, the legitimate heir to his father's title, should resort to Edmunds title and compare himself to him.

- Verbal irony: Edmund sarcastically says' I am "noble as the adversary," since Edmund is not noble. 
Beh Azin makes slight changes to the surface structure, but his meaning is more exact and his language is more natural. Both transfer the irony.

\section{CONCLUSION}

\section{Beh Azin and Peyman and the Ironies}

Beh Azin and Peyman have translated King Lear differently. The main difference between the two translations is in the units of translation they have chosen for different parts of the text. In most instances Beh Azin has chosen smaller units. He has tried to transfer all semantic and structural units and he has followed the surface structural of the TT in many places. It is usually possible to draw a one to one correspondence between the English words and their Persian equivalents in Beh Azin's translations. Accordingly Beh Azin's language is, in many places, so visibly a translation. He is usually unable to provide the ease and naturalness required for a dialogue and stage. Consequently, he is sometimes unable to recreate the emotional quality of the speeches and the tone of the speaker is eclipsed by ambiguity or artificiality of the language. Since the strength of the irony (especially in dramatic, cosmic and situational ironies) depends on the emotional quality of the speech and the tone of the speaker, the ironies in Beh Azin are sometimes weaker in quality. Although he is able to impart the irony in most of the instances, his ironies are lackluster. Beh Azin's emphasis on the meaning of distinct words makes him fit for verbal ironies (see samples 30 and 41).

The unit of translation is usually larger in Peyman. He tends to transfer not words but sentences and sometimes a whole dialogue. He usually disregards the exact dictionary meanings of the words and tries to create equivalent meanings and effects through manipulation of the structure. In many places his dialogues are either shorter or longer that the original and it is almost impossible to draw a one to one correspondence between the English words and the Persian ones. In many places his text looks like an original Persian text and the reader can enunciate parts of it with the ease and naturalness of a fluent Persian text. In other words, instead of translating the words literally, Peyman has tried to discover the exact effect of the speech acts in the context of their cultural and linguistic milieu and to create equivalent Persian speech acts. The act of translating the speech acts has resulted in radical changes in the dictionary meaning of the English words. Peyman's approach to translation is not usually fit for verbal ironies and other figures of speech (for example pun or equivoque) in which double or multiple meaning are worked out. Peyman's translation is fit for cosmic, dramatic and situational ironies where the tone of the speaker and the emotional effects of the speech act are effective. Thus, in cases where both Beh Azin and Peyman are able to transfer a non-verbal irony, the ironies in Peyman are usually stronger and more easily recognized by the reader. Peyman's emphasis on the emotional effect of the speech act makes the dialogues more dramatic and emotional, while Beh Azin's artificial language reduces the dramatic and emotional effect to a great degree.

\section{REFERENCES}

[1] Abrams, M.H. (1985). A Glossary of Literary Terms. (6th ed.) Texas: Harcourt Brace College Publishers.

[2] Beh Azin, M. A. (2012). Translation of Shakespeare's King Lear. Tehran: Dat Publication.

[3] Cutler, A. (1974). On saying what you mean without meaning what you say. In: M.W. Lagaly, R. Fox, \& A. Bruck. (eds.). Papers from the Tenth Regional Meeting of the Chicago Linguistic Society. Department of Linguistics. Chicago: University of Chicago. pp. 117-127.

[4] Corbett, E. P. J. \& R. J. Connors. (1999). Classical rhetorics for the Modern Student. (4th ed.). New York: Oxford University Press.

[5] Dostert, L. E. (1955). “The Georgetown- I. B. M. Experiment.” In Machine Translation of Languages by William N. Locke and A. Donald Booth, 124-135. New York: The Massachusetts Institute of Technology and John Wiley and Sons, Inc.

[6] Goodenough, W. H. (1964). 'Cultural Anthropology and Linguistics', in D. Hymes (ed.) Language in Culture and Society. A Reader in Linguistics and Anthropology. New York: Harper and Row.

[7] Izaias, K. C. O. (2011). The analysis of irony through relevance theory in The Big Bang Theory sitcom. Retrieved March 10, 2014, from: http://revistaseletronicas.pucrs.br/ojs/index.php/belt/article/viewFile/8919

[8] Larson, M. L. (1984). Meaning-Based Translation: A Guide to Cross-Language Equivalence. Lanham \& New York: University Press of America.

[9] Muecke, D. C. (1969). The Compass of Irony. London: Methuen \& Co Ltd.

[10] Peyman, J. (2002). Translation of Shakespeare's King Lear. Tehran: Cultural and Scientific Publication Co.

Mahnaz Havas Beigi was born in Sirvan, Iran, in 1980. She lives in Ilam. She is an M. A. candidate of Translation Studies at Science and Research University of Tabriz, Iran. She received her B. A. in translation from Ilam University, Iran in 2005 . Her main areas of interest include literary translation and English Literature.

Biook Behnam was born in Moghan, Iran, 1957. He holds a Ph.D. in TEFL. He is currently a lecturer in the Department of English Language and Literature of Azad University of Tabriz. His main area of interest is Teaching Language. 